\title{
Pengembangan LKS Berbasis Konteks Lubuklinggau Ditinjau dari Segi Kevalidan dan Kepraktisan
}

\author{
Idul adha ${ }^{1}$, Rani Refianti ${ }^{2}$ \\ ${ }^{1,2}$ Program Studi Pendidikan Matematika, STKIP PGRI Lubuklinggau \\ Email : Idul_Adha12@yahoo.com
}

\begin{abstract}
Abstrak
Penelitian ini dilakukan di SMP N 8 Lubuklinggau tahun pelajaran 2019/2020. Berdasarkan studi pendahuluan yang dilakukan diketahui lembar kerja siswa (LKS) yang digunakan guru merupakan LKS siap pakai yang diperoleh dari penerbit, LKS tersebut memuat rumus, contoh soal disertai pembahasan, tampilan LKSnyapun kurang menarik. LKS dari penerbit tidak relevan dengan konteks lokal daerah setempat, untuk itu dibutuhkan LKS yang dapat memfasilitasi siswa dengan mengedepankan kesesuaikan terhadap konteks lokal . Tujuan dari penelitian ini adalah menghasilkan LKS yang valid dan praktis menggunakan pendekatan matematika realistik Indonesia (PMRI). Penelitian ini menggunakan metode reseach and development menggunakan model 4D yang dimodifikasi menjadi 3D. Tekni pengumpulan data yang digunakan dalam penelitian ini menggunakan teknik angket kevalidan yang diberikan kepada tiga orang ahli yakni ahli bahasa, materi dan media. Angket yang diberikan kepada tiga orang ahli dianalisis untuk mengetahui kevalidan LKS yang dikembangkan. Berdasarkan hasil angket yang diberikan diperoleh skor rata-rata 3,13 LKS berada pada kategori valid. Kepraktisan LKS diketahui dengan memberikan angket kepraktisan kepada siswa pada tahap one to one, small group dan kelompok besar. Angket kepraktisan tersebut selanjutnya dianalisis guna mengetahui sejauh mana kepraktisan LKS yang dikembangkan. Berdasarkan uji kepraktisan LKS yang dikembangkan berada pada kategori praktis dengan skor rata-rata 3,25.
\end{abstract}

Kata kunci : LKS, konteks Lubuklinggau

\section{LKS Development Based on Lubuklinggau Context in Terms of Validity and Practicality}

\begin{abstract}
This research was conducted at SMP N 8 Lubuklinggau in the academic year 2019/2020. Based on the preliminary study, it was found out that the student worksheets (LKS) used by the teacher were ready-to-use worksheets obtained from the publisher, the worksheets contained formulas, sample questions accompanied by discussion, and the appearance of the worksheets was less attractive. The LKS from the publisher is not relevant to the local context of the local area. For this reason, a worksheet is needed that can facilitate students by promoting conformity to the local context. The aim of this study is to produce a valid and practical worksheet using the Indonesian realistic mathematics approach (PMRI). This research uses reseach and development methods using $4 D$ models that are modified to 3D. The data collection techniques used in this study used a validity questionnaire technique given to three experts namely linguists, materials and media experts. Questionnaires given to three experts were analyzed to find out the validity of the worksheets developed. Based on the results of the questionnaire provided an average score of 3.13 LKS is in the valid category. The practicalities of LKS are known by giving practicality questionnaires to students in the one to one stage, small groups and large groups. The practicality questionnaire was further analyzed to determine the extent of the practicality of the worksheet that was developed. Based on the practicality test the worksheet developed was in the practical category with an average score of 3.25.
\end{abstract}

Keywords: LKS, Lubuklinggau context 


\section{PENDAHULUAN}

Lembar kerja siswa (LKS) merupakan bahan ajar yang biasa digunakan dalam pembelajaran. Menurut Estu dan Heru (2017 : 71) LKS merupakan lembaran-lembaran yang berisi petunjuk belajar atau langkah-langkah kegiatan belajar bagi siswa untuk menemukan/memperoleh pengetahuan dari materi yang sedang dipelajari, dengan adanya LKS diharapkan proses pembelajaran lebih maksimal. Norsanty dan Chairani (2016:13) menyatakan fungsi LKS lebih ditujukan untuk memandu siswa dalam menemukan konsep materi yang dipelajari. LKS merupakan salah satu bahan penunjang yang dapat membantu keberhasilan siswa dalam belajar (Refianti \&Adha, 2019:2). Berdasarkan studi pendahuluan yang dilakukan peneliti diketahui bahwa LKS yang digunakan guru merupakan LKS siap pakai yang diperoleh dari penerbit, LKS tersebut memuat rumus, contoh soal dan pembahasan, selain itu tampilan LKSnyapun kurang menarik siswa. Sembiring (2016:16) menyatakan umumnya bahan ajar yang tersedia di pasaran lebih menekankan prosedur dan sedikit sekali memberi peluang bagi siswa untuk mengembangkan kreativitasnya. Rizky dan Rohati (2014 : 98). Kenyataannya LKS yang dimiliki oleh peserta didik selama ini belum memfasilitasi siswa untuk menkonstruksi sendiri pengetahuannya, isi LKS lebih banyak di tekankan pada penjelasan rinci (defenisi) dari sebuah konsep, kemudian di ikuti dengan contoh soal dan sejumlah soal-soal latihan. Hal ini dipertegas oleh Yusuf (2010 : 26) Keberadaan LKS cetak hingga saat ini masih sangat minimal dan belum efektif sebagai sarana pembelajaran. Baik dari segi tampilan, isi maupun kepraktisannya. Akibatnya, siswa mengerjakan LKS cetak dengan perasaan yang terpaksa, kurang bersemangat, dan asal-asalan. Salah satu penyebab penggunaan LKS siap pakai dikarenakan guru tidak terbiasa merancang sendiri LKS dalam pembelajaran matematika sehingga LKS siap pakai merupakan salah satu solusi yang dipilih guru.

Sebelumnya penelitian tentang penggunaan konteks dalam pembelajaran matematika telah banyak dilaksakan beberapa diantaranya penelitian yang dilakukan oleh (Lestari, Darmawijaya, \& Aisyah, 2018) dengan judul pengembangan LKS berbasis teori apos materi bangun ruang sisi datar konteks rumah adat musi banyuasin menghasilkan LKS yang efek potensial terhadap hasil belajar ranah afektif (sikap) dan kognitif (pengetahuan). Penelitian serupa juga dilaksanakan oleh (Mardayanti, Zulkardi, \& Santoso, 2016) dengan judul pengembangan soal open ended menggunakan konteks Sumatera Selatan materi sistem persamaan linear dua variabel kelas X SMA yang menghasilkan soal open ended yang valid dan praktis serta memiliki efek potensial yang positif terhadap hasil belajar siswa. Selanjutnya penelitian juga dilaksanakan oleh (Disnawati \& Nahak, 2019) dengan judul pengembangan lembar kerja siswa etnomatematika tenun timor pada materi pola bilangan yang menghasilkan lembar kerja siswa berbasis etnomatematika tenun Timor yang valid, praktis dan efektif. Selanjutnya (Z, Refianti, \& Mandasari, 2019) dalam penelitiannya yang berjudul pengembangan lembar kerja siswa (LKS) menggunakan contextual teaching and learning berbasis kota Lubuklinggau menunjukan menghasilkan LKS berbasis kota Lubuklinggau yang valid, praktis dan memiliki efek potensial ketuntasan belajar siswa.

Beberapa hasil penelitian tersebut menunjukan bahwa ada banyak sekali konteks dalam kehidupan sehari-hari yang dapat digunakan dalam pembelajaran matematika. Beberapa hasil penelitian tersebut sekaligus menjadi rujukan pengembangan LKS berbasis konteks Lubuklinggau yang dilakukan peneliti. Berdasarkan permasalah yang telah dikemukakan di atas maka diperlukan suatu solusi berupa pengembangan lembar kerja siswa (LKS) yang dapat memfasilitasi kebutuhan akan LKS itu sendiri. Menurut Handayani,dkk (2014 : 2) matematika adalah salah satu materi pembelajaran yang sangat dekat dengan dunia nyata. Ada banyak aktivitas dalam kehidupan yang melibatkan matematika hal ini menunjukan adanya hubungan antara matematika dengan aktivitas sehari-hari. Pembelajaran matematika yang dikaitan dengan sesuatu yang dapat dipahami siswa secara nyata membuat matematika lebih mudah dan menyenangkan untuk itu dalam pengembangan LKS hendaknya menggunakan konteks atau situasi yang sesuai dengan lingkungan tempat siswa berasal. Wijaya (2012 : 21) konteks merupakan titik awal dari suatu pembelajaran matematika yang dikaitkan dengan dunia nyata atau lingkungan sekitarnya, namun konteks juga dapat digunakan dengan pembelajaran alat peraga, permainan, atau situasi lain yang bermakna dan bisa dibayangkan dalam pikiran. Salah satu fungsi dari konteks adalah memberikan siswa suatu akses yang alami dan motivatif 
menunju konsep matematika ( Wijaya, 2012 : 33) Berdasarkan latar belakang tersebut diperlukan lembar kerja siswa (LKS) yang dapat memfasilitasi kebutuhan siswa akan bahan ajar berupa LKS salah satunya dengan mengembangkan lembar kerja siswa menggunakan konteks lubuklinggau yang valid dan praktis.

\section{METODE}

Penelitian ini merupakan penelitian pengembangan (reseach and development) menggunakan model 4D yang dimodifikasi menjadi 3D. Populasi dalam penelitian ini adalah siswa SMP N 8 Lubuklinggau kelas VII tahun pelajaran 2019/2020 yang berjumlah enam kelas. Sampel pada penelitian ini adalah siswa kelas VII.D dan kelas VII.F . Data yang diperoleh pada penelitian ini berasal dari validasi tiga orang ahli yakni ahli materi, ahli media dan ahli bahasa menggunakan angket validasi ahli, data kepraktisan diperoleh dari uji coba pada tahap one to one, small group dan uji kelompok besar dengan menggunakan angket kepraktisan. Data angket yang diperoleh dianalisis menggunakan skala likets dilanjutkan dengan menghitung skor rata-rata dari seluruh aspek yang dinilai dan mengubah skor rata-rata seluruh aspek menjadi nilai kualitatif sesuai dengan kriteria penilaian yang digunakan. Adapun tahapan model pengembangan yang digunakan pada penelitian ini meliputi beberapa tahapan yakni sebagai berikut:

\section{Tahap Pendefinisian}

Pendefinisian adalah langkah pertama dari pengembangan LKS menggunakan model 4-D. Tahap pendefinisian terdiri dari analisis kurikulum, analisis siswa, analisis kebutuhan siswa.

\section{Tahap Perancangan}

Tahap perancangan bertujaan untuk menyiapkan prototipe LKS yang dirancang. Tahap perancangan terdiri dari penyusunan tes acuan patokan, pemilihan media dan pemilihan format LKS.

\section{Tahap Pengembangan}

Tahap pengembangan bertujuan untuk menghasilkan LKS yang valid dan praktis. Ada beberapa hal yang dilakukan pada proses pengembangan yakni meliput validasi LKS oleh para ahli yang terdiri tiga orang ahli yakni ahli materi ahli materi, ahli media dan ahli bahasa, hasil dari validasi ketiga orang ahli selanjutnya dianalisis guna mengetahui apakah LKS yang dikembangkan valid atau tidak berdasarkan validasi ketiga ahli. Validasi ahli dilakukan bersamaan dengan proses one to one atau uji coba kelompok kecil. Hasil dari validasi ahli dan one to one selanjutnya direvisi untuk diujicobakan pada kelompok kecil (small group) yang terdiri dari enam orang siswa dengan kriteria kemampuan yang berbeda beda. Selanjutnya hasil dari ujicoba LKS pada kelompok kecil direvisi dan diujicobakan pada kelompok besar. Secara keseluruhan diagram alir dari penelitian model pengembangan 4-D yang digunakan untuk mengembangkan Lembar kerja siswa berbasis konteks Lubuklinggau terlihat pada Gambar 1. 


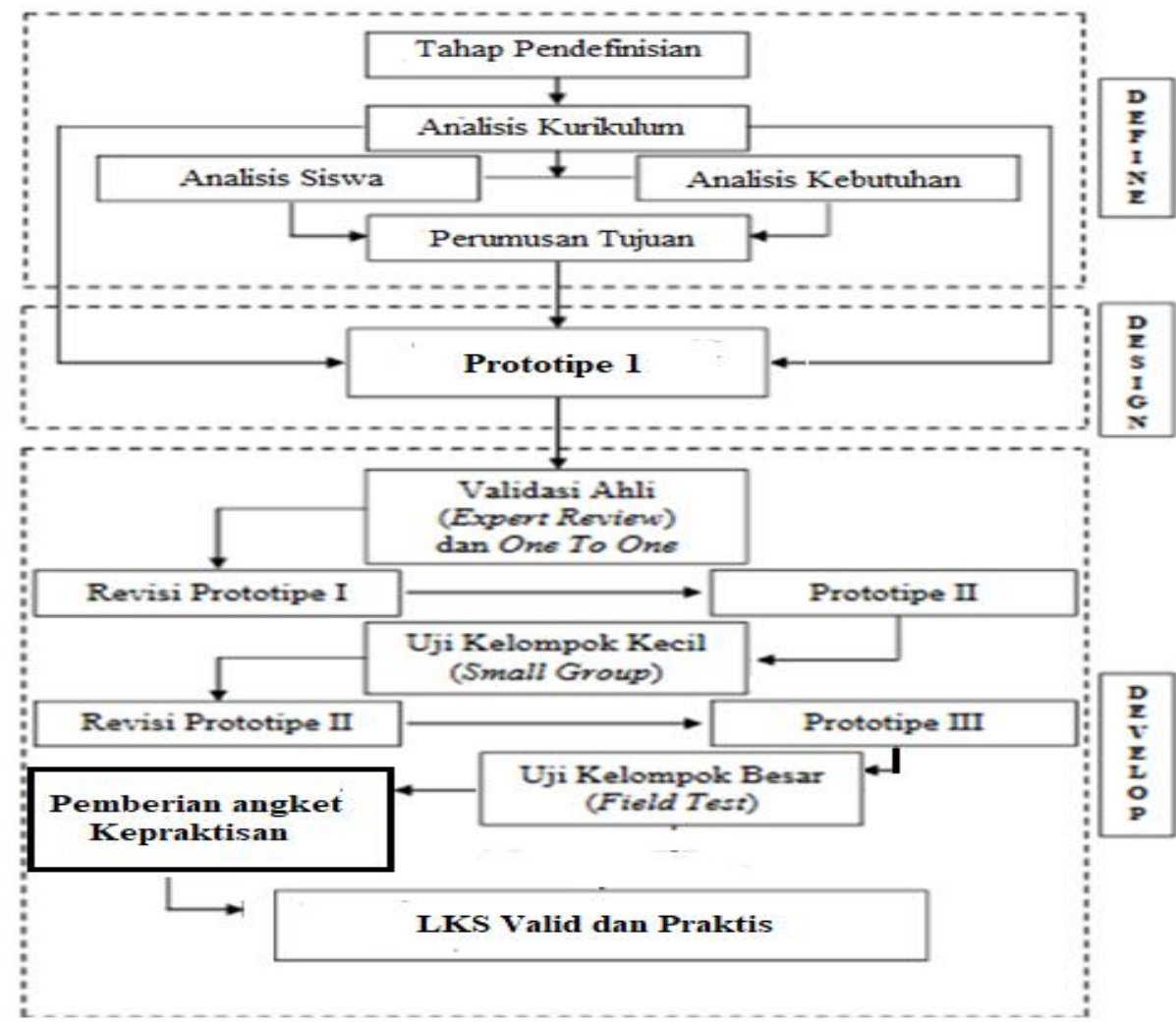

Gambar 1. Tahapan Pengembangan (Modifikasi Thiagarajan, Semmel, \& Semmel (Trianto, 2010)

\section{Teknik Pengumpulan Data dan Analisis Data}

Analisis Angket analisis data angket dibagi dua yakni analisis data angket untuk siswa dan analisis data angket untuk ahli.

1. Analisis data angket ahli

a. Angket ahli digunakan untuk mengetahui sejauh mana kevalitan LKS yang dikembangkan. Angket ahli diberikan kepada ahli bahasa, ahli materi dan ahli media. Angket ahli di analisis dengan menggunakanpedoman penskoran untuk ahli bahasa, ahli materi dan ahli media pada Tabel 1

Tabel 1. Pedoman Penskoran Kevalidan LKS

\begin{tabular}{cc}
\hline Skor & Kriteria \\
\hline 4 & Sangat baik \\
3 & Baik \\
2 & Kurang baik \\
1 & Sangat kurang baik \\
\hline
\end{tabular}

(Sugiono, $2015: 166$ )

b. Menghitung skor rata-rata.

c. Mengubah skor rata-rata seluruh aspek menjadi nilai kualitatif dengan kriteria penilaian pada Tabel 2. 
Tabel 2. Kriteria Kevalidan LKS

\begin{tabular}{cc}
\hline Nilai & Kriteria \\
\hline$X>3,4$ & Sangat valid \\
$2,8 \leq X \leq 3,4$ & Valid \\
$2,2 \leq X \leq 2,8$ & Cukup valid \\
$1,6 \leq X \leq 2,2$ & Kurang valid \\
$X \leq 1,6$ & Sangat kurang valid \\
\hline & (Yuliana, 2017:63)
\end{tabular}

2. Analisis angket siswa

Pemberian angket siswa dilakukan untuk mengetahui sejauh mana kepraktisan LKS yang dikembangkan. Dimana jawaban setiap item instrument dapat menggunakan skala likert dengan kriteria sangat positif sampai sangat negative dengan kategori sangat setuju (ST), setuju (S), tidak setuju (TS), sangat tidak setuju (STS). Angket kepraktisan siswa dianalisis mengikuti ketentuan sebagai berikut :

a. Angket kepraktisan siswa dianalisis menggunakan skala likert dan dianalisis dengan ketentuan Tabel 3.

Tabel 3. Pedoman Penilaian Lembar Kepraktisan LKS

\begin{tabular}{cc}
\hline Nilai & Pernyataan \\
\hline 4 & Sangat setuju \\
3 & Setuju \\
2 & Tidak setuju \\
1 & Sangat tidak setuju \\
\hline
\end{tabular}

(Sugiono, $2015: 166$ )

b. Menghitung skor rata-rata dari seluruh aspek yang dinilai

c. Mengubah skor rata-rata seluruh aspek menjadi nilai kualitatif sesuai dengan kriteria penilaian kepraktisan yang dijabarkan dalam tabel 4 .

Tabel 4. Kriteria Tingkat Kepraktisan

\begin{tabular}{cc}
\hline Nilai & Kriteria \\
\hline$X>3,4$ & Sangat praktis \\
$2,8 \leq X \leq 3,4$ & Praktis \\
$2,2 \leq X \leq 2,8$ & Cukup praktis \\
$1,6 \leq X \leq 2,2$ & Kurang praktis \\
$X \leq 1,6$ & Sangat kurang praktis \\
\hline
\end{tabular}

(Yuliana, $2017: 63$ )

\section{HASIL DAN PEMBAHASAN}

Berdasarkan langkah-langkah pengembangan yang telah dikemukakan di atas, tahap penelitian pengembangan ini terdiri dari tahap pendefinisian, tahap perancangan dan tahap pengembangan. Pada tahap pendefinisian peneliti melakukan observasi dan wawancara dengan salah satu guru matematika di SMP Negeri 8 Lubuklinggau kelas VII yakni Ibu Rusnila Emi. Adapun hasil yang diperoleh pada observasi dan wawancara yaitu: 1). Kurikulum yang digunakan di SMP N 8 Lubuklinggau yakni menggunakan kurikulum 2013, 2). peninjauan mengenai materi yang dirasa sulit, 3). pembelajaran matematika di sekolah menggunakan LKS siap pakai sebab guru tidak terbiasa mendesain sendiri LKS 4). Siswa tidak begitu tertarik dengan LKS yang digunakan sebab tampilan LKS nya kurang menarik dengan kertas yang buram 5). Sebagian siswa tidak menyukai pembelajaran matematika sebab dirasa sulit, siswa membutuhkan bahan ajar yang dapat memfasilitasi kebutuhan mereka akan pembelajaran 
matematika. Langkah terahir dari tahap pendefinisian adalah melakukan perumusan tujuan pembelajaran yang merupakan penjabaran dari standar kompetensi (SK) dan kopetensi dasar (KD) pada materi yang dirasa sulit bagi siswa. Perumusan tujuan pembelajaran merupakan dasar dari merancang LKS.

Tahap perancangan bertujaan untuk menyiapkan prototipe LKS yang dirancang. Tahap ini menghasilkan rancangan awal LKS. Tahap ini meliputi penyusunan format LKS dan pemilihan model/pendekatan penyajian. Hasil dari tahap ini berupa LKS tahap pertama (Prototipe 1). Selanjutnya pada tahap pengembangan bertujuan untuk menghasilkan LKS yang valid dan praktis serta memiliki efek potensial terhadap hasil belajar siswa. Tahap pengembangan terdiri dari:

1. Validasi LKS oleh pakar dilakukan oleh tiga orang ahli yakni ahli materi, ahli media dan ahli bahasa. Hasil validasi ahli dianalisis untuk mengetahui kelayakan LKS ditinjau dari aspek kevalidan. Hal ini dilakukan sebagai pengambilan keputusan apakah LKS yang dikembangkan layak untuk dilakukan ujicoba kelompok kecil. Uji coba one to one dilakukan bersamaan dengan validasi pakar. Hasil uji coba one to one dan validasi pakar dianalisis kemudiaan dilakukan perbaikan berdasarkan saran-saran dan komentar yang diperoleh. Gambar 1 dan Gambar 2 merupakan salah satu hasil dari validasi pakar yang menunjukan perubahan dari prototipe 1 (sebelum revisi) ke prototipe 2 (setelah revisi)

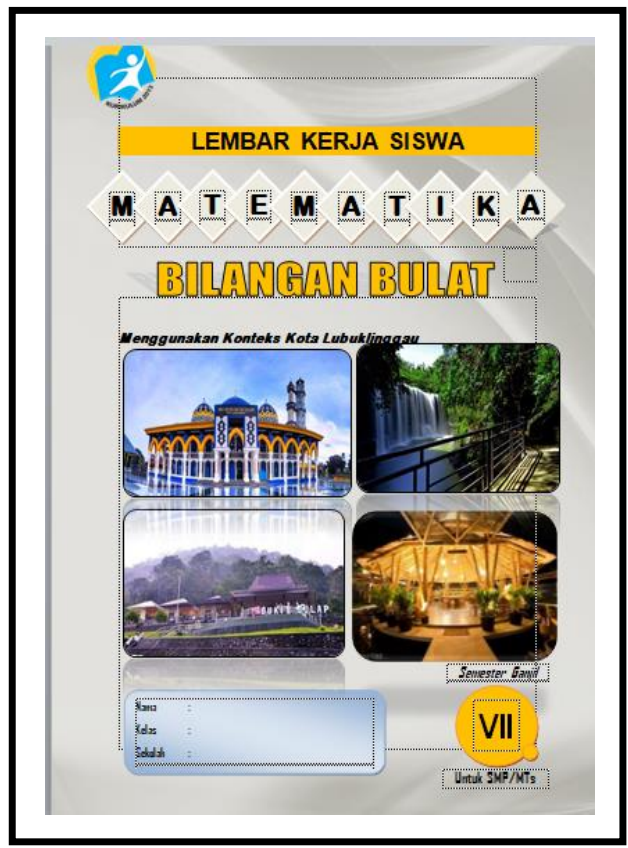

Gambar 2 Sebelum revisi

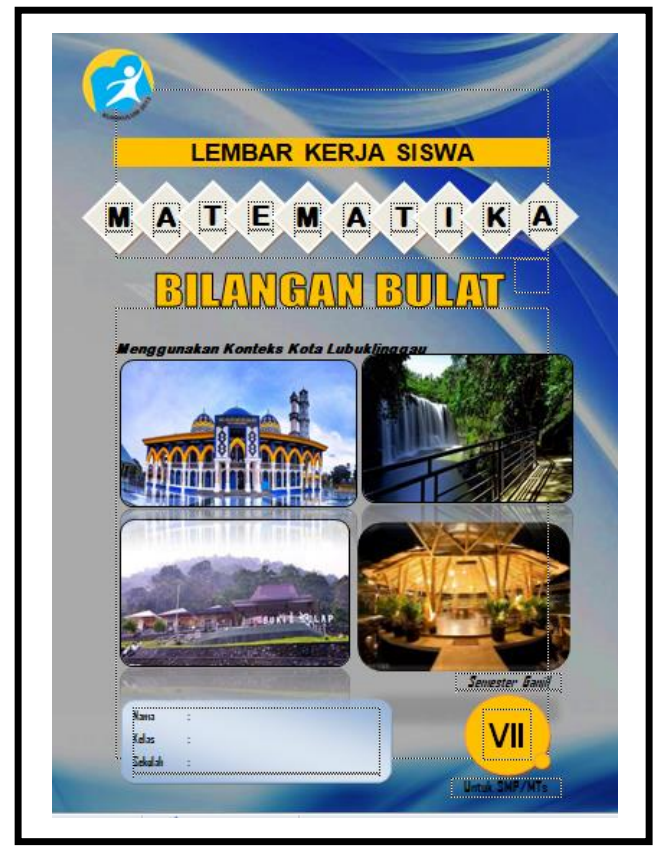

Gambar 3 Setelah revisi

Pada prototipe 1 (Gambar 1) warna cover LKS yang digunakan kurang terang dan pada saat validasi oleh ahli media diminta melakukan perbaikan pada bagian cover LKS agar tampilannya lebih menarik. Hasil revisi dapat dilihat pada Gambar 2. Prototipe 1 yang telah divalidasi oleh ahli selanjutnya diperbaiki berdasarkan saran yang diberikan, hasil dari revisi prototipe 1 menghasilkan prototipe 2 yang selanjutnya siap di uji cobakan pada kelompok kecil (small group)

2. Prototipe 2 LKS di uji cobakan pada kelompok kecil (small group) untuk melihat aspek kepraktisan dari penggunaan LKS dan sebagai pertimbangan mengambil keputusan untuk diujicobakan pada kelompok besar. Selanjutnya prototipe 2 direvisi berdasarkan komentar dan saran-saran siswa pada kelompok kecil. Hasil dari revisi prototipe 2 menghasilkan prototipe 3 yang selanjutnya akan diujicobakan pada kelompok besar. 
3. Prototipe 3 diuji cobakan pada kelompok besar dengan tujuan untuk mengetahui kelayakan LKS ditinjau dari aspek kepraktisan dengan pemberian angket pada siswa. Adapun hasil rekapitulasi ketiga ahli dapat dilihat pada Tabel 5.

Tabel 5. Rekapitulasi Hasil Penilaian Para Ahli
\begin{tabular}{ccc}
\hline No & \multicolumn{1}{c}{ Ahli } & Hasil \\
\hline 1. & Ahli Bahasa & 3 \\
2. & Ahli Materi & 3,3 \\
3. & Ahli Media & 3,1 \\
\hline Rata-Rata & $\mathbf{3 , 1 3}$ \\
\hline Kategori & Valid \\
\hline
\end{tabular}

Berdasarkan hasil uji analisis kevalidan yang dilakukan oleh tiga orang ahli yakni ahli bahasa, ahli materi dan ahli media diperoleh skor rata-rata sebesar 3,13 berada pada kategori valid. Hal ini menunjukan bahwa LKS yang dikebangkan layak digunakan berdasarkan hasil angket validasi yang diberikan kepada ketiga orang ahli. Uji kepraktisan dilakukan pada tahap one to one, smaall group dan uji kelompok besar. Uji kepraktisan dilakukan dengan memberikan angket kepraktisan kepada siswa setelah pembelajaran menggunakan LKS berbasis konteks lubuklinggau materi bilangan bulat selesai dilakukan. Pada uji kepraktisan masing-masing siswa diminta mengisi angket kepraktisan selanjutnya anggket uji kepraktisan dianalisis dan untuk menentukan skor rata-ratanya. Berikut hasil rekapitulasi angket kepraktisan dapat dilihat pada Tabel 6.

\begin{tabular}{|c|c|c|}
\hline No & Tahapan & Hasil \\
\hline 1 & One to one & 3,17 \\
\hline 2. & Small group & 3,12 \\
\hline 3. & Kelompok besar & 3,46 \\
\hline \multicolumn{2}{|c|}{ Rata-Rata } & 3,25 \\
\hline \multicolumn{2}{|c|}{ Kategori } & Praktis \\
\hline
\end{tabular}

Berdasarkan uji kepraktisan diperoleh skor rata-rata sebesar 3,25 berada pada kategori praktis hal ini menunjukkan bahwa LKS yang dikembangkan praktis digunakan oleh siswa. Hal ini senada dengan penelitia yang dilkakukan oleh (Prabawati, Yanto, \& Mandasari, 2019) dalam temuan penelitiannya mengemukaan bahwa Lembar kerja siswa (LKS) yang dikembangkan berada pada kategori valid dan sangat praktis. Hasil temuan serupa juga diperoleh oleh (Oktarina, Luthfiana, \& Refianti, 2019) yang mengembangkan lembar kerja siswa (LKS) etnomatematika berbasis temuan terbimbing berada pada kategori valid dan praktis serta memiliki efek potensial terhadap hasil belajar siswa dengan persentase ketuntasan 76,9\%.

Berdasarkan fakta di atas peneliti dapat menarik kesimpulan bahwa lembar kerja siswa (LKS) merupakan salah satu bahan ajar yang efektif digunakan dalam pembelajaran di sekolah, Penggunaan LKS di sekolah hendaknya disesuaikan dengan konteks lokal budaya setempat. Artinya dalam pengembangan LKS diselaraskan dengan lingkungan tempat tinggal siswa. Hal ini dapat meningkatkan pemahaman siswa terhadap pembelajaran matematika, sekaligus sebagai sarana agar konteks lokal setempat dapat dikenal secara lebih luas.

\section{SIMPULAN}

Berdasarkan hasil penelitian dapat disimpulkan bahwa lembar kerja siswa (LKS) yang dikembangkan berada pada kategori valid dan praktis dengan skor rata-rata kevalidan 3,13 dan skor rata-rata kepraktisan 3,25. Hal ini menunjukan bahwa LKS yang dikembangkan layak digunakan dalam proses pembelajaran, sekaligus dapat menjadi sumber rujukan bagi peneliti lain dalam mengembangkan lembar kerja siswa (LKS) hendaknya disesuaikan dengan kondisi lingkungan siswa. 


\section{DAFTAR PUSTAKA}

Disnawati, H., \& Nahak, S. (2019). Pengembangan Lembar Kerja Siswa Berbasis Etnomatematika Tenun Timor Pada Materi Pola Bilangan. Jurnal Elemen, 5(1), 64-79

Estu \& Heru. (2017). Pengembangan Perangkat Pembelajaran Lembar Kerja Siswa Dengan Pendekatan Kontekstual Untuk Meningkatkan Kemampuan Pemecahan Masalah Siswa. Jurnal Mercumatika, Vol 2 No. 1

Handayani,dkk. (2014). Keefektifan Auditory Intelectually Repetition Berbantu LKPD

Lestari, D., Darmawijaya, \& Aisyah, N. (2018). Pengembangan LKS Berbasis Teori Apos Materi Bangun Ruang Sisi Datar Kontes Rumah Adat Musi Banyu Asin. Kreano, 9(1), 1-9.

Mardayanti, E., Zulkardi, \& Santoso, B. (2016). Pengembangan Soal Open Ended Menggunakan Konteks Sumatera Selatan Materi Sistem Persamaan Linear Dua Variabel Kelas X SMA. Jurnal Pendidikan Matematika, 10(1), 1-15.

Norsanty, U.O., \& Chairani, Z. (2016). Pengembangan Lembar Kerja Siswa (LKS) Materi Lingkaran Berbasis Pembelajaran Guided Discovery untuk Siswa SMP Kelas VIII. Jurnal Pendidikan Matematika, 2 (1), 12-23.

Oktarina, A., Luthfiana, M., \& Refianti, R. (2019). Pengembangan Lembar Kerja Siswa (LKS) Etnomatematika Berbasis Penemuan Terbimbing Pada Materi Bangun Ruang Sisi Datar. Jurnal Pendidikan Matematika (Judika Education), 2(2), 91-101.

Prabawati, R., Yulfitri, Y., \& Novianti, M. (2019). Pengembangan LKS Berbasis PMRI Menggunakan Konteks Etnomatematika Pada Materi SPLDP. Jurnal Pendidikan Matematika (Judika Edication), 2(2), 73-79.

Refianti, R., \& Adha, I. 2019. Pengembangan Lembar Kerja Siswa (LKS) Menggunakan Pendekatan Matematika Realistik Indonesia Berbasis Konteks Sumatera Selatan. Jurnal Pendidikan Matematika (Judika Education), Vol. 2(1) : 1-10.

Rizky \& Rohati. (2014). Pengembangan Lembar Kerja Siswa (LKS) Berbasis POE (Predict, Observe, Explain) Pada Materi Program Linier Kelas XII SMA. Jurnal Sainmatika Vol 8 No 1.

Sembiring. (2010). Pendidikan Matematika Realistik Indonesia Perkembangan dan Tantangannya. IndoMS. J.M.E. Vol. 1 No 1

Sugiyono. (2015). Metode Penelitian \& Pengembangan: Research and Development. Bandung: Alfabeta.

Trianto. 2010. Model Pembelajaran Terpadu: Konsep, Strategi dan Implementasinya dalam Kurikulum Tingkat Satuan Pendidikan (KTSP). Jakarta: Bumi Aksara.

Wijaya. (2012). Pendidikan Matematika Realistik, Suatu Alternatif Pendekatan Pembelajaran Matematika. Yogyakarta: Graha Ilmu. 
Yuliana, R. 2017. Pengembangan Perangkat Pembelajaran dengan Pendekatan PMRI pada Materi Bangun Ruang Sisi Lengkung untuk SMP Kelas IX. Jurnal Pendidikan Matematika, Vol. 6(1) : 60-67

Yusuf, M. (2010). Peningkatan Hasil Belajar Matematika Melalui Lembar Kerja Siswa (LKS) Interaktif Berbasis Komputer Di SMA Muhammadiyah 1 Palembang. Jurnal Pendidikan Matematika. Vol 4 No 2

Z, M., Refianti, R., \& Mandasari, N. (2019). Pengembangan Lembar Kerja Siswa (LKS) Menggunakan Contekstual Teaching and Learning Berbasis Kota Lubuklinggau. Jurnal Pendidikan Matematika (Judika Education), 2(2), 102-109. 